\title{
SURVEY AND EFFORTS TO IMPROVE MITIGATION ABILITY FOR DISABILITY STUDENTS IN GORONTALO CITY
}

\author{
Reskiyanto Fauzi Duwingik ${ }^{1}$, Della Nawarita P. Kasim ${ }^{1}$, Dewi Ayu ${ }^{1}$, \\ Moh. Aristo Dano ${ }^{1}$, Intan Noviantari Manyoe ${ }^{1}$ \\ ${ }^{1}$ Geological Engineering Major, Departement Of Earth Science and Technology, Faculty of Mathematics \\ and Natural Science, Universitas Negeri Gorontalo, Indonesia \\ Email Corresponding: reskieki50@gmail.com
}

DOI: $10.31314 /$ jsig.v2i1.249

Abstract - The condition of Gorontalo City has a high level of vulnerability to earthquake hazards, for this reason an understanding of earthquakes needs to be done early, especially for children with disabilities. This study aims to determine the level of understanding of earthquake mitigation for students with disabilities in SDLB Gorontalo, especially the blind, deaf, and autism and to find the efforts to improve the mitigation ability of disability students. The method that will be used in this study is the survey method with the instrument used in the form of a questionnaire. The samples in this study were 34 people with disabilities in SDLB of Gorontalo City consisting of blind, deaf and autism students. The results obtained are the level of understanding and ability of students for earthquake mitigation is very low (not good category) where for blind people is $3.5 \%$, while deaf is $1.6 \%$, and autism is $0.1 \%$. For this reason, efforts need to be done to improve the ability of disabilities with cheerful learning media such as cheerful music for the visually impaired, attractive images for the deaf, and for autism given attractive images accompanied by gifts for what they do to improve their abilities and their learning enthusiasm.

Keyword: disability, students, ability, earthquake, mitigation, gorontalo

\section{INTRODUCTION}

Sulawesi Island, especially the northern arm, is included in the region with very high earthquake intensity, this is because the region is under pressure from the northern Sulawesi Sea which activates Sulawesi Sea subduction and Gorontalo Fault (Pasau and Tanauma. 2011). The Gorontalo region, particularly Gorontalo City, is one of the areas prone to earthquake disasters, due to the Gorontalo Fault that cuts across the Gorontalo City area (Pasau et al., 2014). Gorontalo City area has a peak ground acceleration of 21,780 gal where the cause comes from the activity of Gorontalo Fault (Manyoe et al, 2019).

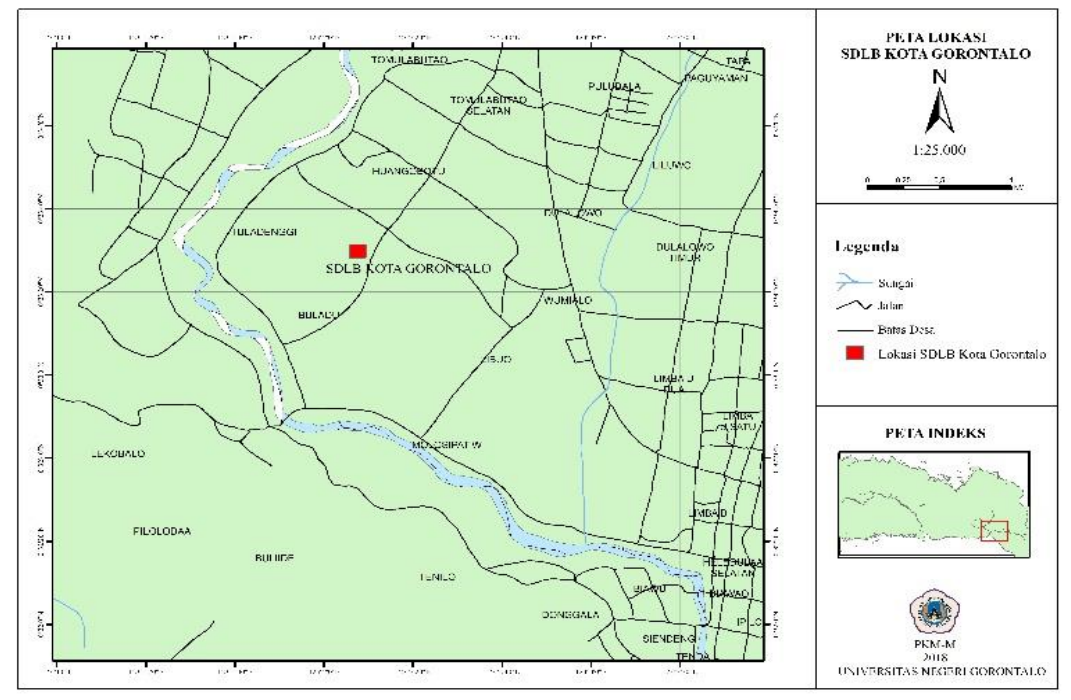

Figure 1. Location of Research 
Based on data from Gorontalo Province Disaster of Management Agency (BNPB), the earthquake intensity in the Gorontalo City area is classified as a high earthquake hazard. This certainly can cause problems such as damage to infrastructure such as highways, office buildings and schools that have an impact on community activities and can even endanger the safety of children, especially children with disabilities in Gorontalo City. This study aims to determine the level of understanding and ability of mitigation in students with disabilities, especially blind, deaf, and autism students in the SDLB of Gorontalo City and to find the efforts to improve mitigation ability of disability students.

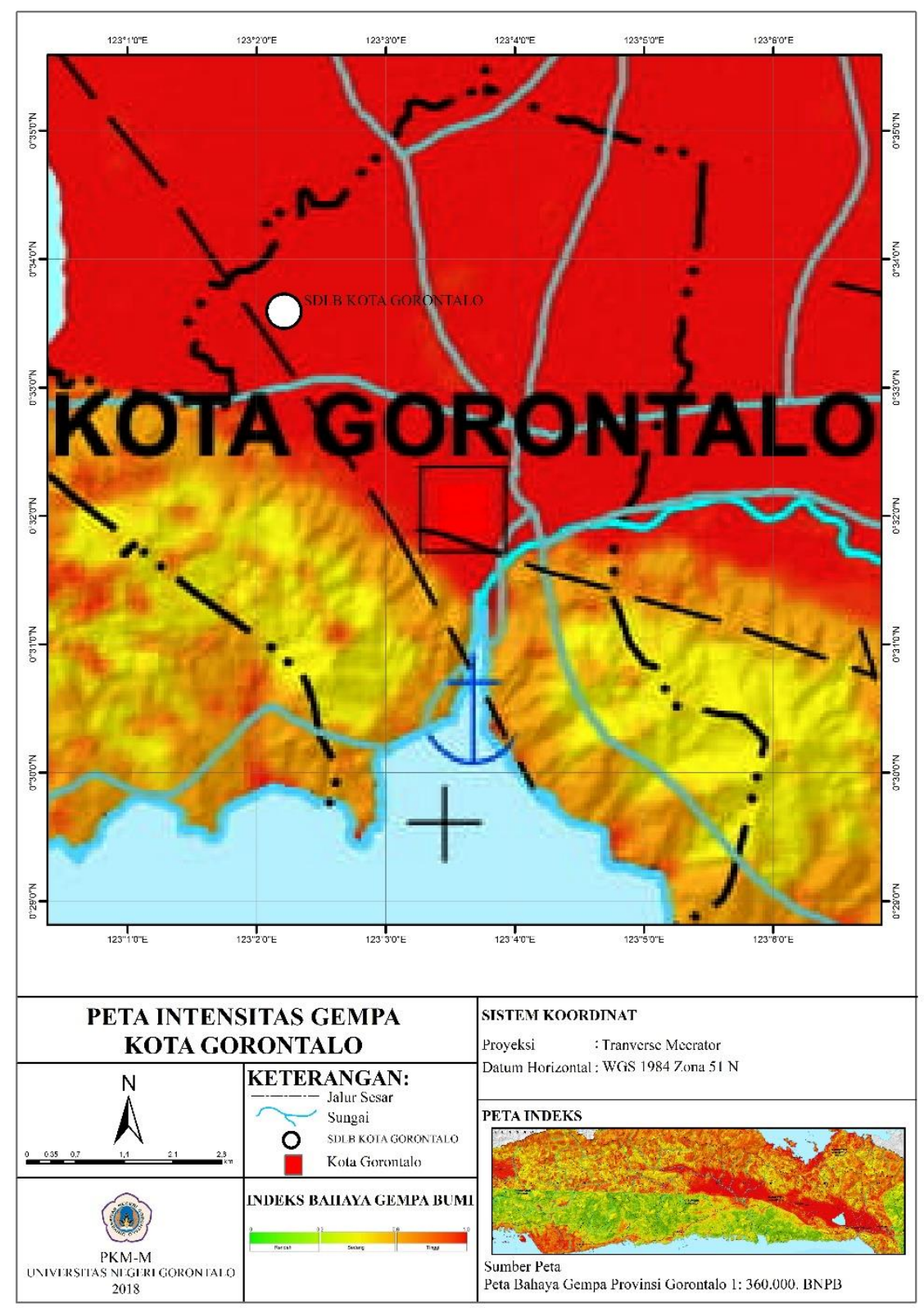

Figure 2. Level of the Eartquake in Gorontalo City

\section{DATA AND METHOD}

The method used in this study is the method of survey conducted directly children with disabilities in SDLB Gorontalo City with a total samples of 34 people where the samples used involves the entire population consisting of blind people as many as 2 people, deaf 25 people, and autistic 7 people. This study uses an instrument in the form of a questionnaire containing simple questions about their understanding and knowledge of earthquakes and their mitigation ability. Then based on the results of the survey, the total score of each person with disability is calculated 
using the formula:

$$
X=\frac{\sum x}{n} \times 100 \%
$$

Information:

$X \quad$ : Average score

$\sum \mathrm{x}$ : Number of Scores

$\mathrm{N}$ : Number of Respondents

Table 1. Table of Student Response level (Sumber: Azwar, 2011)

\begin{tabular}{cc}
\hline $\mathbf{X}$ & Category \\
\hline $80 \% \leq \mathrm{X} \leq 100 \%$ & Very Good \\
$60 \% \leq \mathrm{X}<100 \%$ & Good \\
$40 \% \leq \mathrm{X}<100 \%$ & Good enough \\
$20 \% \leq \mathrm{X}<40 \%$ & Poor \\
$\mathrm{X}<20 \%$ & Not Good \\
\hline
\end{tabular}

\section{RESULT AND DISCUSSION}

Based on the results of the survey, it was seen that students knowledge of the earthquake was very low (not good category) where for blind knowledge of earthquake mitigation was $3.5 \%$, while deaf was $1.6 \%$, and for autism patients was $0.1 \%$. Based on the diagram below (Figure 4), the level of understanding of students with disabilities to earthquake mitigation is very low. The highest level of understanding among all samples is in blind people because they still have good listening skills so they can still receive information well. Deaf is ranked second which has the highest level of understanding among all samples. This is because they have limited hearing. Unlike the case with blind and deaf, children with autism have the lowest level of understanding. This is influenced by their own behavior, for it needs initial therapy to be able to control their emotions.

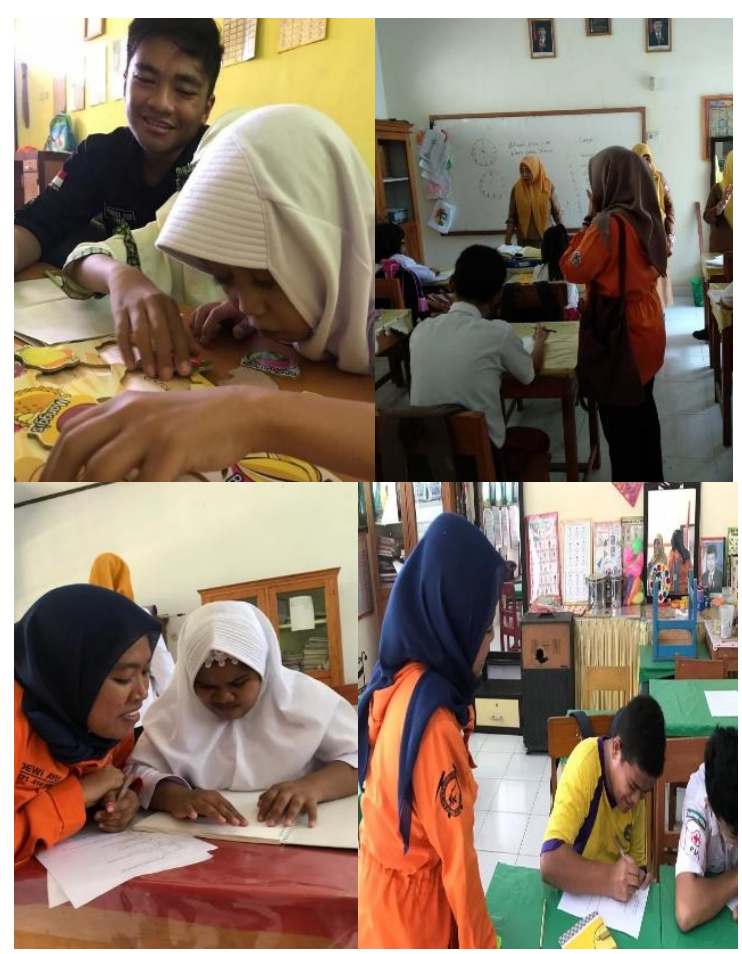

Figure 3. The Process of Survey on Blind, Deaf, and Austism 
There needs to be an effort to increase their ability in terms of disaster mitigation with fun learning to increase learning, enthusiasm in children with blind, deaf and autistic. Blind children have good listening skills. The use of cheerful music will greatly help them to remember every material given. Improved earthquake understanding and mitigation ability in blind children can be given using music and songs. Improved earthquake understanding and mitigation abilities in deaf children can be given using the picture and writing media that display mitigation measures. For autistic children, attractive images accompanied by gifts for each of what they do will be able to improve their learning abilities and enthusiasm (Pamuji, 2014). Understanding of earthquakes and mitigation steps can be given using simple images and short words.

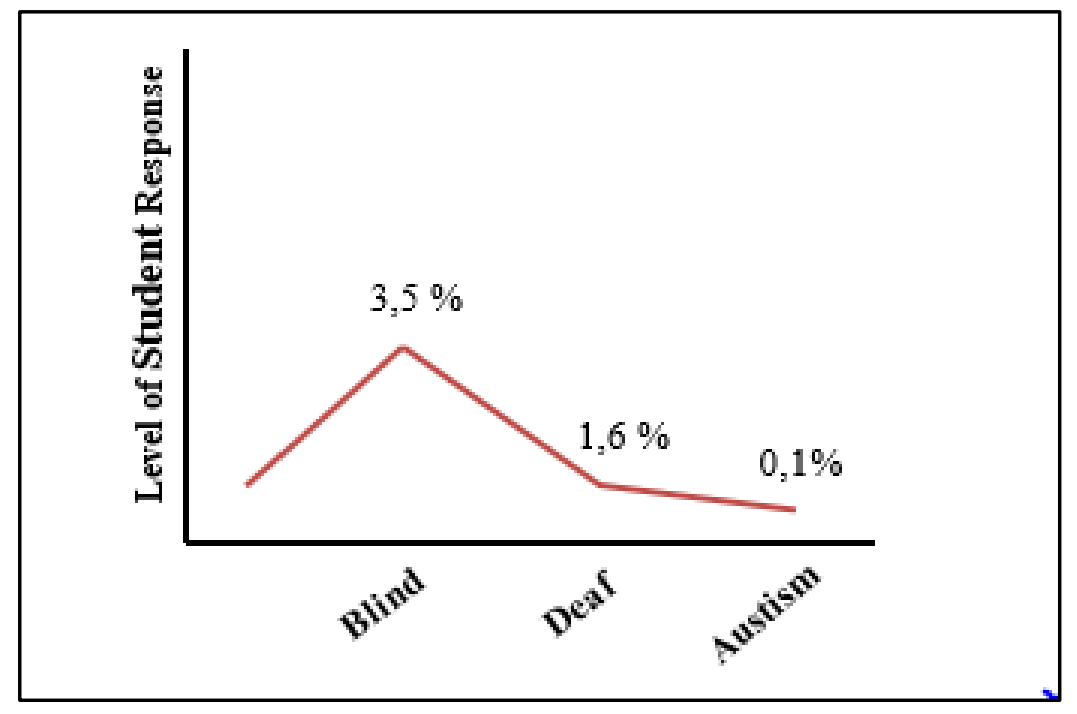

Figure 4. Diagram of Student Level Understanding for Mitigation of Earthquake Disaster

\section{CONCLUSIONS}

The earthquake understanding and mitigation of disability students is very low where for blind people the knowledge of earthquake mitigation is 3.5\%, while Deaf is $1.6 \%$, and for autistic is $0.1 \%$. This will certainly be dangerous for themselves when an earthquake occurs. For this reason, efforts must be made to improve the ability of the three persons with disabilities, such as cheerful music for the blind, attractive images for the deaf, and for autism to be provided with attractive images accompanied by gifts for what they do to improve their abilities and their enthusiasm for learning.

\section{AKNOWLEDGEMENTS}

The authors would like to thank you to RISTEKDIKTI for funding support in this study. As well as all parties involved in this research so that this research can be carried out properly.

\section{REFERENCES}

Manyoe, I. N., Arif, S., \& Lahay, R. J. (2019). Earthquake Damage Level of Gorontalo Area Based on Seismicity and Peak Ground Acceleration. Jambura Geoscience Review, 1(1), 7 12.

Pasau, G., \& Tanauma, A. (2011). Pemodelan Sumber Gempa di Wilayah Sulawesi Utara Sebagai Upaya Mitigasi Bencana Gempa Bumi. Jurnal Ilmiah Sains, 11(2), 202-209.

Pasau, G., \& Raharjo, S. S. (2014). Identifikasi Sesar di Wilayah Gorontalo dengan Analisis Mekanisme Bola Fokus. Jurnal MIPA, 3(1), 40-43.

Pamuji, P. (2014). Adaptasi Media Pembelajaran Gambar Untuk Meningkatkan Aktivitas Belajar Anak Autis. Jurnal Ortopedagogia, 1(2), 117-127. 